\title{
Bias correction and downscaling of snow cover fraction projections from regional climate models using remote sensing for the European Alps
}

\author{
Michael Matiu ${ }^{1}$, Florian Hanzer ${ }^{2}$
}

$5 \quad{ }^{1}$ Institute for Earth Observation, Eurac Research, Bolzano, 39100, Italy

${ }^{2}$ Department of Geography, University of Innsbruck, Innsbruck, 6020, Austria

Correspondence to: Michael Matiu (mmatiu.eurac@gmail.com)

\begin{abstract}
.
Mountain seasonal snow cover is undergoing major changes due to global climate change. Assessments of future snow cover usually rely on physical based models, and often include post-processed meteorology. Alternatively, here we propose a direct statistical adjustment of snow cover fraction from regional climate models by using long-term remote sensing observations. We compared different bias correction routines (delta change, quantile mapping, and quantile delta mapping) and explore a downscaling based on historical observations for the Greater Alpine Region in Europe. All bias correction methods adjust for systematic biases, for example due to topographic smoothing, and reduce model spread in future

15 projections. Averaged over the study region and whole year, snow cover fraction decreases from 12.5\% in $2000-2020$ to 10.4 (8.9, 11.5; model spread) \% in 2071-2100 under RCP2.6, and 6.4 (4.1, 7.8) \% under RCP8.5. In addition, changes strongly depended on season and altitude. The comparison of the statistical downscaling to a high-resolution physical based model yields similar results for the altitude range covered by the climate models, but different altitudinal gradients of change above and below. We found trend-preserving bias correction methods (delta change, quantile delta mapping) more plausible

20 for snow cover fraction than quantile mapping. Downscaling showed potential but requires further research. Since climate model and remote sensing observations are available globally, the proposed methods are potentially widely applicable, but are limited to snow cover fraction only.
\end{abstract}

\section{Introduction}

Mountain regions store large amounts of precipitation in form of snow and ice, which provide essential water supply for

25 downstream regions, affecting an estimated quarter of humanity (Immerzeel et al., 2020). Global warming resulted in significant changes of the cryosphere with melting glaciers and shifts in the timing and abundance of snow (Huss et al., 2017), which already affected the hydrological cycle (Morán-Tejeda et al., 2014) and will continue to do so in the future (Hanzer et al., 2018). These changes imply consequences in water supplies for domestic use, hydropower, and agriculture. Seasonal snow cover responds rapidly to climate variability and change, in contrast to glaciers, which are out of balance with 
30 current climate and will, to some extent, continue to melt even if climate targets are achieved (Marzeion et al., 2018). Finally, besides acting as water storage, snow cover has significant atmospheric feedbacks with its high albedo, modulating mountain weather (Wallace and Minder, 2021) and causing large uncertainties in climate projections of northern hemisphere land warming (Thackeray et al., 2018).

Snow cover can be modelled using a large variety of models, which can be roughly grouped into conceptual empirical models (e.g., temperature index models such as Hock, 2003), complex energy-balance models with snow physics (e.g., Brun et al., 1989), and simplified energy-balance models with few layers, which are used in land-surface schemes of climate and hydrological models (e.g., Zanotti et al., 2004). In order to estimate future snow cover, conceptual empirical models can fail under the non-stationarity assumption of a changing climate, while the most complex energy balance models might be computationally unfeasible or accumulate artefacts in long-term simulations.

40 Recently, regional climate models (RCMs) have become a feasible alternative to study large scale snow cover (Räisänen and Eklund, 2012), even in complex terrain such as the European Alps (Steger et al., 2013), owing to increases in resolution and modelling performance. Using snow cover output directly from RCMs, instead of taking meteorological forcing from RCMs and feeding it into dedicated snow models, has some benefits. First, it provides a consistent physical signal with landatmosphere feedbacks. Second, it removes the need to perform bias correction of meteorological input for the dedicated snow model. The main downside of RCMs is their coarse resolution and limited representation of snow processes, which can be a limiting factor especially for mountain areas. For example, the EURO-CORDEX (European branch of the Coordinated Regional Climate Downscaling Experiment) scenarios for Europe are available at $0.11^{\circ}$. However, single higher resolution runs of RCMs at 1-5km are available (Warscher et al., 2019; Lüthi et al., 2019), but they still lack the breadth of the EUROCORDEX ensemble with up to 55 members (Coppola et al., 2021), which allows to assess multiple scenarios and model 50 uncertainty. Additionally, RCMs suffer from biases, such as for temperature and precipitation (Vautard et al., n.d.), which would be the meteorological forcing for dedicated snow models, but also from biases in RCM snow cover. For instance, snow water equivalent (SWE) is largely overestimated in RCMs in high mountain regions (Steger et al., 2013; Terzago et al., 2017). On the other hand, snow cover fraction from RCMs has been shown to be reproduced well, and even snow depth, when accounting for elevation and temperature differences (Matiu et al., 2020b). It should be noted that gridded estimates of

55 SWE are prone to large uncertainties, especially in high mountain regions, while snow cover fraction can be inferred with high accuracy from remote sensing (Largeron et al., 2020).

Before climate model output can be used for climate change assessments or impact models, it usually undergoes some postprocessing, such as bias correction and downscaling. These serve to overcome systematic biases between observations and model output, which can be caused by model inadequacies, inherited biases in RCMs from their driving GCMs (general 60 circulation models), or biases associated to the mismatch between spatial resolution of reference observations and model. The reference observations can be points or grids, often limited in extent compared to RCMs, and, in the case of grids, of usually higher resolutions. 
The simplest form of bias correction is the delta-change (DC) approach, where the mean climate change signal (e.g., in temperature) is superimposed on the observation series. However, DC cannot reflect any change in the future distribution of the considered variable. The most widely used approach for bias correction is quantile mapping (QM), which can simultaneously perform downscaling, too. QM matches observed and modelled distributions and the non-parametric variant performs better in reproducing observed climatology than parametric versions (Gudmundsson et al., 2012). An extension is quantile delta mapping (QDM), which is a trend-preserving approach to QM (Cannon et al., 2015), since QM has been shown to modify trends in a few cases (Maurer and Pierce, 2014). The flexibility, performance, and ease-to-use has made QM or QDM a standard approach for national climate change assessments, see, for example, Switzerland $(\mathrm{CH} 2018,2018)$ or Germany (Krähenmann et al., 2021).

For assessing future changes in snow cover based on climate model scenarios, two methods are mainly employed. The first is to use downscaled and bias corrected meteorological forcing from climate models to drive dedicated snow or hydrological models (DeBeer et al., 2021; Hanzer et al., 2018). The second is to use directly snow cover output from climate models (see above). However, the availability of long-term high-resolution satellite imagery has enabled a third option: To use remote sensing for bias correction and downscaling of RCM snow cover. To the best of our knowledge, this has not yet been performed. We restrict the study to snow cover fraction only, and not snow depth or SWE, because it is the only snow variable available at high resolution and with high accuracy in mountain terrain, in addition to the method thus being potentially applicable globally.

80 The aims of this study are to bias correct and downscale snow cover fraction from RCMs using remote sensing observations for the European Alps, and to compare this, for a limited area, to the use of a dedicated snow model forced by downscaled RCM meteorology. The motivation is that the snow cover fraction biases of RCMs were shown to be mainly caused by orography and temperature, partly also precipitation, mismatches (Matiu et al., 2020b), which are systematic biases that can be statistically corrected, while future change estimates should be consistent. While bias correction cannot add information

85 beyond what is contained in the RCM, it can reduce model spread and it can make information on future projections more meaningful: absolute values are better than change estimates both for climate change information and for impact assessments, which often depend on absolute thresholds. By exploiting the morphological dependence of snow cover on topography, downscaling can improve the local spatial representation of RCM snow cover fraction. Finally, the comparison between downscaling RCMs and using a snow model shall highlight benefits and limitations of both approaches.

90 The study combines the proof-of-concept of applying bias correction and downscaling to snow cover fraction with its application to assess future scenarios of snow cover fraction over the European Alps. The remainder of the paper is as follows. Section 2 introduces the study region and data sets. Section 3 explains the methods used for bias correction and downscaling. Section 4 presents results and discussion, and Section 5 the conclusion. 
https://doi.org/10.5194/hess-2021-449

Preprint. Discussion started: 23 September 2021

(c) Author(s) 2021. CC BY 4.0 License.
Hydrology and

Earth System

Sciences

Discussions

\section{Data}

95 The study region is roughly what is called the Greater Alpine Region in Europe, which contains the European Alps and spans, in this study, approximately $43-48.5^{\circ} \mathrm{N}$ and $5-17^{\circ} \mathrm{E}$ (Fig. 1). The large-scale climatic setting includes influences from the Atlantic Ocean, the Mediterranean Sea, and the European continent. The region is characterized by complex topography with strong elevational gradients. The comparison of statistical downscaling to a dedicated snow model is performed for a small subset, the Ötztal Alps region in Austria $\left(1850 \mathrm{~km}^{2}, 862-3770 \mathrm{~m}\right.$ a.s.1., Fig. $1 \mathrm{~b}$ and 1d); see Hanzer et

100 al. (2018) for a detailed description of the region.

\section{(a)}

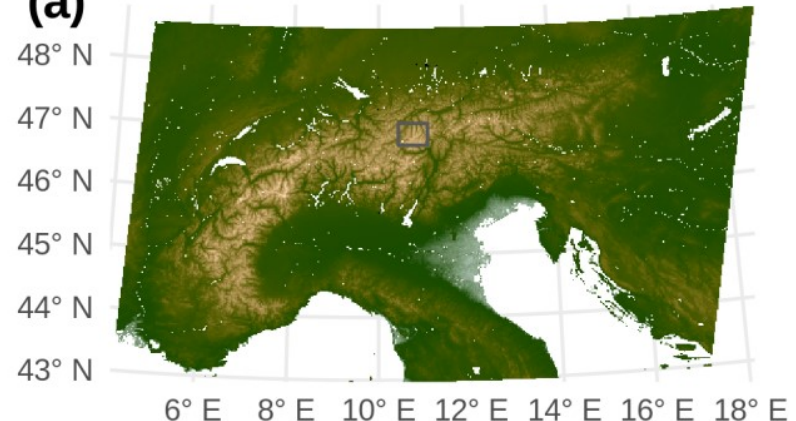

(c) $48^{\circ} \mathrm{N}$
$47^{\circ} \mathrm{N}$
$46^{\circ} \mathrm{N}$
$45^{\circ} \mathrm{N}$
$44^{\circ} \mathrm{N}$ m.a.s.l.

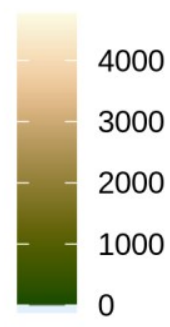

$\operatorname{SCD}[\mathrm{d}]$

300

200

100 (b)

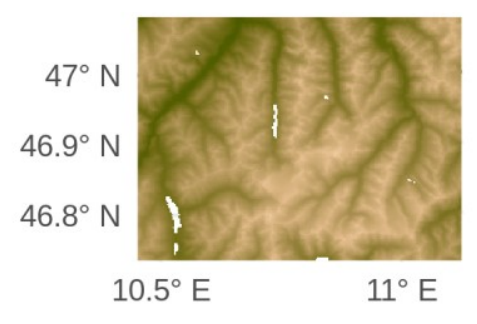

(d)

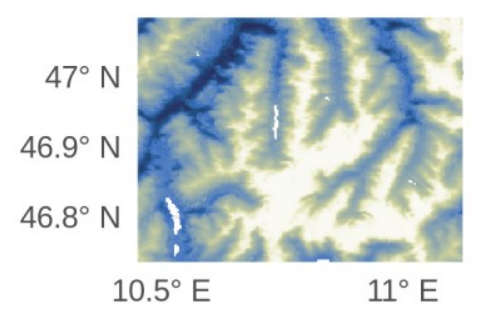

Figure 1: Topography (a-b) and average annual snow cover duration from remote sensing for the hydrological years 2001-2019 (cd) of the study region, the European Alps, $(a, c)$ as well as the Ötztal Alps region (b, d), also indicated with a tiny square in (a) and (c). 


\subsection{Observed snow cover fraction from remote sensing}

110 As for remote sensing observations, we relied on MODIS (Moderate Resolution Imaging Spectroradiometer), because it offers the best tradeoff between temporal availability (two decades, daily) and spatial resolution ( $250 \mathrm{~m}$ nominal) to perform a downscaling - in contrast to coarser products such as based on AVHRR (Advanced Very-High-Resolution Radiometer), which have a longer period into the past (starting in the 1980s), but are of coarse resolution and less quality for complex mountain terrain than higher resolution sensors. A cloud filtered product was used (Matiu et al., 2020a), which is based on

115 the snow maps developed in Notarnicola et al. (2013a). The processing included temporal and elevational (spatial) filters to remove nearly all cloud coverage. Compared to Matiu et al. (2020a), here we used only Terra acquisitions, thus extending the temporal extent back to 2000. Otherwise, the processing is the same, only the first step (merging of Terra and Aqua) was omitted. Consequently, daily cloud-free binary (snow/land) snow cover maps were available for the complete period 200002-24 to 2020-08-23 at $250 \mathrm{~m}$ nominal resolution (232 m effectively) in Lambert azimuthal equal-area projection for the domain denoted in Fig. 1.

The high-resolution binary snow maps were aggregated into low-resolution snow cover fraction maps that match the RCM resolution of $0.11^{\circ}$, which is approximately 8.6 by $12.2 \mathrm{~km}$ for the Alps. Each low-resolution pixel then contained 1961 $(37 * 53)$ high-resolution pixels.

\subsection{Snow cover fraction from regional climate models}

125 The EURO-CORDEX ensemble consists of 11 RCMs driven by 8 GCMs from CMIP5 (Coupled Model Intercomparison Project Phase 5); see Coppola et al. (2021) for more information on the general ensemble setup. However, not all models provide all variables and/or all emission scenarios. For this study, we used the RCP2.6 (representative concentration pathway) and RCP8.5 scenarios, where RCP2.6 is likely to keep global warming below $2^{\circ} \mathrm{C}$ until 2100 , while RCP8.5 corresponds to approximately $5^{\circ} \mathrm{C}$ global warming. Regarding snow cover fraction (SNC), the available ensemble for this

130 study included, for RCP8.5, 6 RCMs driven by 6 GCMs with a total of 29 simulations, and, for RCP2.6, 4 RCMs driven by 5 GCMs with a total of 8 simulations (Table S1). The list of used RCMs is CLMcom-CCLM4-8-17, CLMcom-ETH-COSMOcrCLIM-v1-1, CNRM-ALADIN63, IPSL-WRF381P, KNMI-RACMO22E, and SMHI-RCA4. Even though DMIHIRHAM5 also provides SNC, we excluded it because the SNC values over the Alps are unrealistically low, although snow depths match very good (Matiu et al., 2020b).

135 The RCM SNC grids were reprojected onto the low-resolution MODIS maps using nearest neighbor resampling in order to have a one-to-one correspondence of pixels in the spatial domain. Nearest neighbor was favored over other resampling methods, such as bilinear, because it preserves the two-sided bounded nature of SNC, which goes from 0 to 1 , and thus keeps the same limits, while bilinear resampling can introduce lower maxima or higher minima.

Some models display snow accumulation issues (Terzago et al., 2017; Matiu et al., 2020b; EURO-CORDEX Errata, 2021)

140 and affected grid cells were removed based on thresholds on snow water equivalent or snow depth, as described in Matiu 
(2020b). These were mostly grid cells with the highest elevation and the number of affected cells was between 0 and 233 , depending on model, out of a total of approximately 5000 land grid cells in the study domain (see Figure S1 and Table S2 for location and number of affected cells by RCM). Spatial averages and ensemble means are based on the common subset of pixels available to all models. KNMI-RACMO22E was strongly affected by snow accumulation, and thus we removed it from results that show spatial/ensemble means, since otherwise too many pixels would have to be removed. Consequently, for calculating ensemble means, 23 simulations were available for RCP8.5, but only 4 for RCP2.6.

\subsection{Snow cover fraction from AMUNDSEN}

The fully distributed snow and hydroclimatological model AMUNDSEN (Strasser, 2008), now available as openAMUNDSEN in Python (Warscher et al., 2021), has been previously applied to study the future snow and ice evolution in the Ötztal Alps region in Austria (Hanzer et al., 2018); see Fig. 1b and 1d for the area. AMUNDSEN dynamically resolves the mass and energy balance of snow and ice and has been driven by future meteorology based on EURO-CORDEX RCMs, which includes a subset of the same RCMs mentioned above. The input meteorology has been bias corrected and downscaled using QM to point scale, and further temporally disaggregated and spatially distributed to provide 3 hourly forcing at $100 \mathrm{~m}$ horizontal resolution for the whole catchment. For more details, see Hanzer et al. (2018). The modelled snow water equivalents were converted into snow cover fraction using a threshold of $5 \mathrm{~mm}$. We also evaluated a threshold of $15 \mathrm{~mm}$ but found differences to be negligible.

For the comparison, we decided to focus on ensemble means, and not compare results between individual GCM-RCM pairs directly. Only few RCMs overlap between Hanzer et al. (2018) and this study. In addition, the QM that has been applied in Hanzer et al. (2018) removes single GCM-RCM biases for the past period and thus renders comparison less meaningful. Finally, the ensemble size is similar, since Hanzer et al. (2018) used 14 GCM-RCM for RCP8.5 and 3 GCM-RCM pairs for RCP2.6, compared to 19 and 3 here, respectively (CNRM-ALADIN63 was removed, because half of the Ötztal Alps area was affected by snow accumulation).

\section{Methods}

\subsection{Bias correction of snow cover fraction}

We compared four different bias correction methods, which are routinely applied for temperature and precipitation series, in their applicability for bias correcting snow cover fraction: delta change (DC), quantile mapping (QM, Gudmundsson et al.,

170 2012), quantile delta mapping (QDM, Cannon et al., 2015), and multivariate QDM (Cannon, 2018). In all cases, the past refers to period of available MODIS observations, which is 2000 to 2020. For the climate model runs, the historical period, 
which goes from 1950/70 to 2005, was merged to the RCP scenario run, which covers 2006 to 2100, in order to have the same common period for the past as available from MODIS (2000 to 2020). Thus, for applying the bias correction, each scenario had its own past time series (i.e., for each RCP scenario), while usually the calibration is performed on the same historical run for all scenarios, usually 1970-2000. However, this was not possible here, since the overlap between historical period and MODIS is only 5 years, which is too little to derive robust distributional estimates of the snow cover climatology. As future period, we considered 2071 to 2100 . The bias correction was applied for the same spatial $\left(0.11^{\circ}\right)$ and temporal scale (daily).

For the DC approach, we calculated the multiplicative change ratios between the past and future from RCMs and applied it

180 to the observations from MODIS. This was done separately for each grid cell and each month. For QM and QDM, we employed the standard routines using empirically derived distribution functions (Gudmundsson et al., 2012; Cannon et al., 2015), as available in the R packages qmap and MBCn, again month-by-month and pixel-by-pixel. For QDM, multiplicative change ratios were used. The multivariate QDM was applied in the spatial domain, thus the multivariate component was to account for the spatial correlation in SNC between pixels. However, we found results to be almost identical to standard univariate QDM, and we do not show it further in results. We assume this similarity to be caused by the high spatial correlation in SNC, and the fact that this spatial correlation is similar in both model and observed series.

Because SNC is bounded not only at the minimum 0 but also at the maximum of 1, the standard QM and QDM algorithms had to be modified. We applied the trace condition, which sets all values below a threshold (here: 0.001 , also called trace value) to exact zeros, also to the maximum of 1 . In addition, the distribution of RCM SNC contained many exact zeros and ones in comparison to observed SNC, which was more regularly distributed across the $[0,1]$ interval, caused by the sub-grid variability in observations. This caused problems in estimating and matching the modelled and observed quantiles. To alleviate this issue, we added a random component to all SNC values near 0 and 1 , where near means half of the trace value. The random values were randomly sampled from a uniform distribution with minimum the machine epsilon (the lowest value without rounding issue in floating point arithmetic) and maximum half the trace value, i.e., effectively from the [0, 0.0005] interval. This random component helps in matching quantiles (and thus distributions) but breaks the temporal consistency in the bias corrected SNC time series.

\subsection{Downscaling of snow cover fraction to binary snow}

The proposed downscaling approach converts low-resolution snow cover fraction (SNC) from RCMs into high-resolution binary snow cover (snow/land), from which we extracted monthly and annual snow cover duration (SCD). The downscaling is based on the morphological dependence of snow cover (Premier et al., 2021). It uses a conditional probability approach (Dong and Menzel, 2016) to define the relationship between snow cover fraction of a low-resolution pixel and the 
probability of a high-resolution pixel being snow-covered or snow-free. We used the 20 years of daily MODIS snow maps to calculate the conditional probability that a high-resolution pixel is snow-covered depending on the SNC of the lowresolution MODIS pixel, which has been aggregated from the high-resolution maps. For this, we summed up the occurrence of snow per high-resolution pixel for a sequence of low-resolution SNC bins of width 0.05 with additional bins at the minimum and maximum to catch nearly exact zeros and ones (i.e., 0, 0.001, 0.05, 0.1, . 0.95, 0.999, 1). See Figure S2 for estimated probabilities by SNC bins for an example area. Probabilities were only estimated, if more than 30 observations were available per low-resolution pixel and SNC bin.
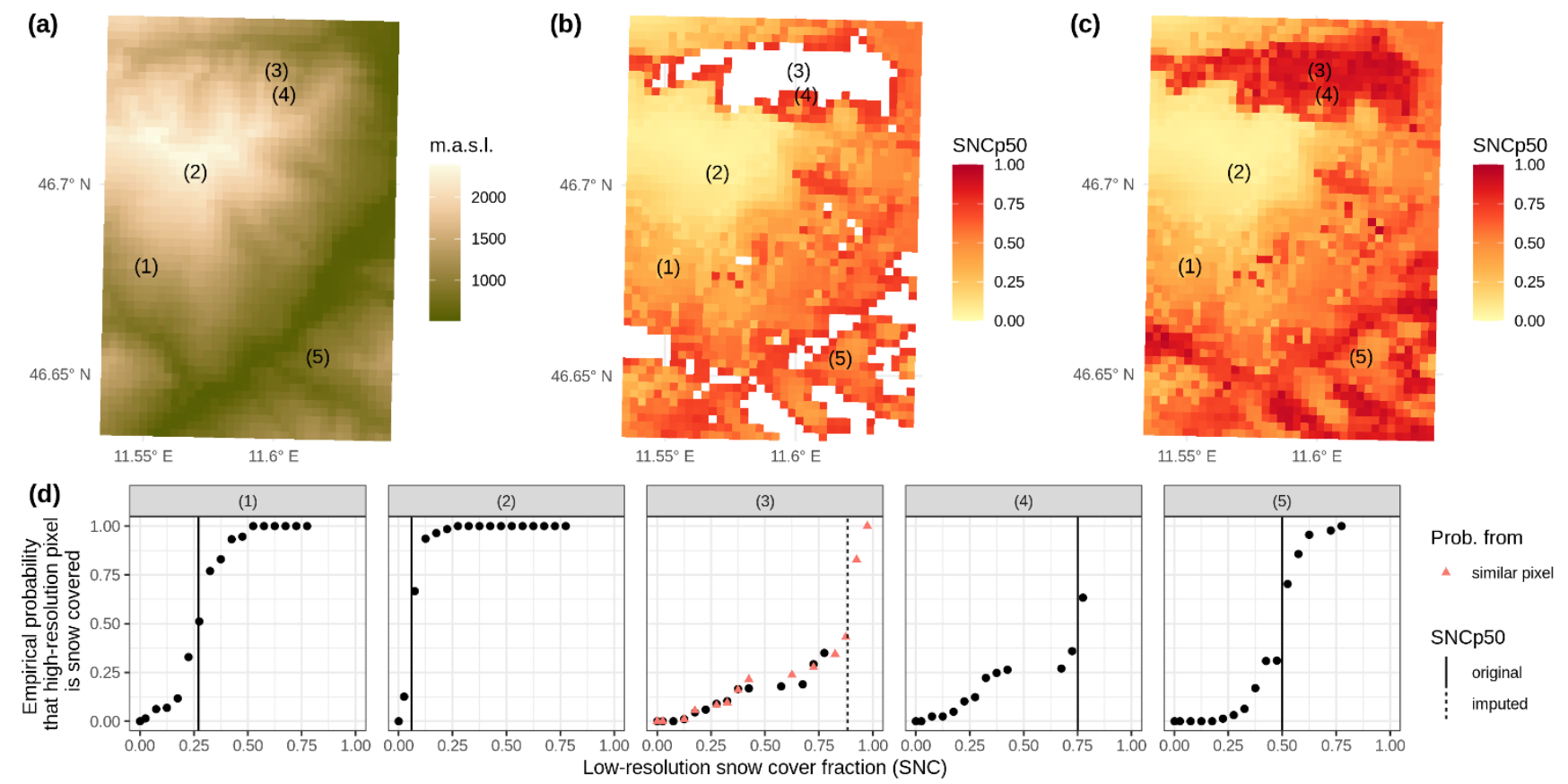

Prob. from

$\Delta$ similar pixel

SNCp50

| original

215 Figure 2. Downscaling method exemplified at one low-resolution pixel. (a) Elevation of high-resolution pixels within example lowresolution pixel. (b) Low-resolution snow cover fraction threshold at which the probability that the high-resolution pixel is snow covered exceeds 0.5 (SNCp50). (c) Same as (b) but after imputation based on similarity of probability curves (as well as similarity of low-resolution sub-grid topography). (d) Empirically estimated probability curves that high-resolution pixels are snow covered depending on the low-resolution snow cover fraction. Labels (1) to (5) denote five example high-resolution pixels in panels (a-d).

The downscaling is then performed by estimating the SNC value for which the probability of a pixel being snow covered is higher than 0.5 , called SNCp50 from now on. For this, the SNC threshold at which the probability exceeds 0.5 was estimated from the empirical relationship by linear approximation. An example is shown in Fig. 2, which shows the expected negative relationship between SNCp50 and elevation, which implies that, as SNC increases from 0 to 1 , the snow cover is more likely 
to be found going from high to low elevations. But while elevation is the main influence, SNCp50 can vary considerably for similar elevations (e.g., points (1), (3), and (4) in Fig. 2 are approximately the same elevation) due to local terrain factors. In order to have a unique solution for SNCp50, the relationship between low-resolution SNC and probability of highresolution snow needs to be non-strictly monotonic, which is a physically valid assumption for any given high-resolution pixel. However, because of noise and errors in the MODIS time series, this was not always the case, so we selected the longest non-strictly increasing subsequence to calculate SNCp50. To have robust estimates of this threshold, we removed nearly exact zeros and ones, thus requiring some points that identify the shape of the curve (Fig. 2d). For 36\% of pixels, the linear approximation failed to estimate SNCp50, because either no empirical estimates were available (except for ones and zeros) or all were above/below 0.5 (see, e.g., point (3) in Fig. 2d). For these pixels, SNCp50 was imputed in two steps.

235 First, we applied a similar pixel approach ( $\mathrm{Li}$ et al., 2020) to select another reference pixel with available SNCp50 that is similar with respect to the sub-grid topography of the encompassing low-resolution pixel and to the high-resolution probability curves. For this, we identified similarity between low-resolution pixels, by calculating the Wasserstein distance (also called earth-mover distance) between the high-resolution elevations in all pairs of low-resolution pixels. The Wasserstein distance is a distance metric applicable to distributions, where no one-to-one correspondence can be expected.

240 For each high-resolution pixel with missing SNCp50, we selected the 50 nearest low-resolution pixels (including the lowresolution pixel with missing high-resolution SNCp50). Then, we calculated the mean absolute error (MAE) between SNC probability curves for pixels that deviate at most $150 \mathrm{~m}$ of the missing pixel elevation and have at least 5 values to compare SNC probability curves. The SNCp50 from the pixel with minimal MAE was used to fill the gap. After this step, 29\% remained missing, most located above 3000 or below $500 \mathrm{~m}$.

245 The second step involved a simpler elevation filter, and no comparison of probability curves. Again, we selected the 50 most similar low-resolution pixels, and from these up to 100 high-resolution pixels with at most $150 \mathrm{~m}$ elevation difference to the gap pixel. The average SNCp50 from these maximum 100 pixels was then used to fill the gap. This step left $<0.001 \%$ pixels missing.

A rough estimate of the downscaling performance was calculated by applying the downscaling to the QM or QDM bias corrected past model runs, which, by definition, have a matching empirical distribution in SNC to the low-resolution MODIS SNC. Thus, the difference between downscaled average annual snow cover duration (SCD) and observed high-resolution MODIS SCD is an indicator of the downscaling error. The mean downscaling bias was $-3.7 \mathrm{~d}$ and the MAE $5.7 \mathrm{~d}$. In addition, there was an elevation dependence of the bias (Figure S3). A negative bias was found for elevations below $1000 \mathrm{~m}$, almost no average bias between 1000 and $3000 \mathrm{~m}$, and positive bias above $3000 \mathrm{~m}$. Glacierized surfaces exhibited strong positive bias, except if SNCp50 was imputed by the second elevational step. We excluded glacierized pixels with more $10 \%$ glacierized area from the further analysis of the downscaling, because of this systematic bias in addition to the difficulties of distinguishing snow and ice with MODIS (Fugazza et al., 2021). In addition, they had a strong overlap with the already removed low-resolution RCM pixels with snow accumulation (Sec. 2.1). Glacier extents were extracted from the Randolph Glacier Inventory 6.0 (RGI Consortium, 2017). 
https://doi.org/10.5194/hess-2021-449

Preprint. Discussion started: 23 September 2021

(C) Author(s) 2021. CC BY 4.0 License.

(c) (P)
Hydrology and

Earth System

Sciences

Discussions

260 The downscaling was applied to both QM and QDM bias corrected low-resolution snow cover fraction. However, in the results we put emphasis on QDM, because the trend preserving attribute is preferred for ratio variables, such as precipitation and SNC, as compared to interval variables, such as temperature (Cannon et al., 2015).

\section{Results and Discussion}

\subsection{Bias correction and future changes in snow cover fraction}

The RCMs reproduced overall seasonal and large-scale spatial patterns of past snow cover fraction well (cf. RAW in Fig. 3 and 4). For instance, Winter (December-February) snow cover fraction spatial patterns agreed not only for the high-elevation Alpine region, but also for lower elevation mountains, such as the northern Alpine foreland, Dinarides, or the Northern

270 Apennines. However, because of the coarse resolution and smoothed model orography, the RCMs did not capture the fine scale complex patterns found in the Alps (Fig. 4). Additionally, they revealed some spread in under- and overestimating snow cover fraction, which depended both on RCM and GCM (Fig. 3), as has also been shown previously (Terzago et al., 2017; Matiu et al., 2020b). This model bias depended stronger on the RCM and only secondly on the driving GCM.

Applying DC, QM and QDM bias correction to past RCM output enforced it to match the distribution of observed SNC and consequently also reduced the model spread for the future (Fig. 3). In addition, it introduced the fine-scale spatial patterns into the smoothed model output (Fig. 4). QM and QDM, by definition, resulted in the same patterns for the past. Bias corrected future estimates were similar for the two trend preserving approaches DC and QDM, which themselves differed substantially from QM. For example, QM showed less reduction in SNC under the RCP8.5 scenario for spring (March-May) than DC and QDM (Fig. 3 and 4). 


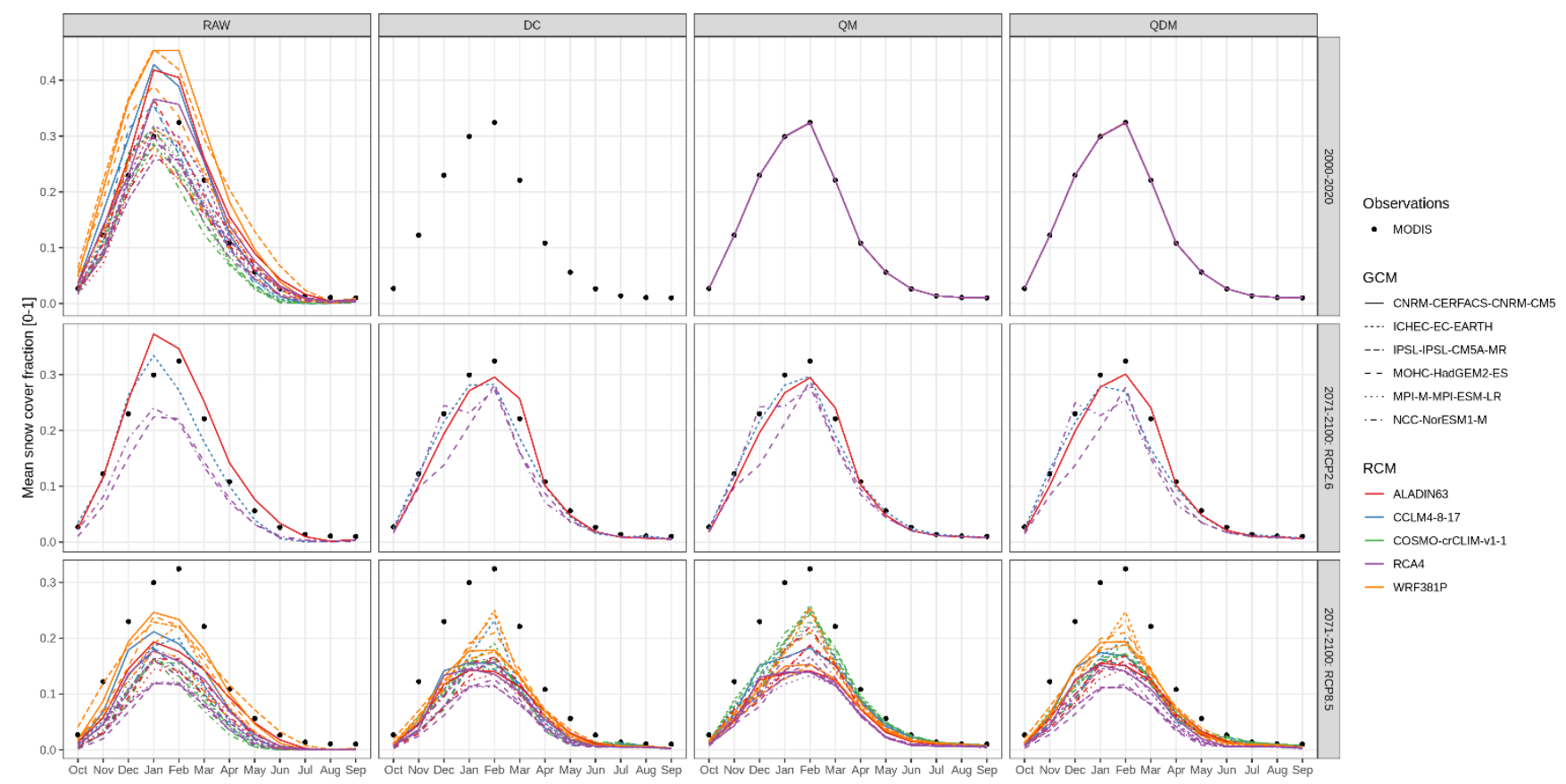

Figure 3. Average monthly snow cover fraction over the whole study domain. Black points denote observations from remote sensing for the period 2000-2020 (the same in all panels), and colored lines the regional climate model (RCM) simulations with associated general circulation model (GCM). First row shows monthly averages for the past (2000-2020), while the middle and last row are for 2071-2100 averages for two emission scenarios (RCP, representative concentration pathway). Column RAW is for original RCM output, DC is the delta change approach, QM is quantile mapping, and QDM quantile delta mapping. 

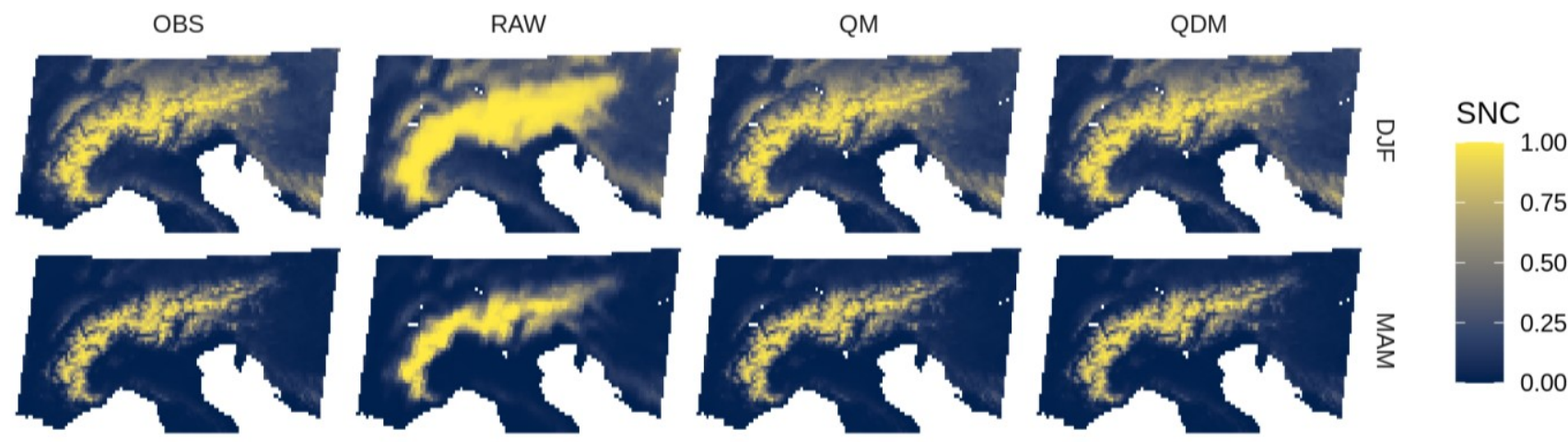

Future (2071-2100)

DC
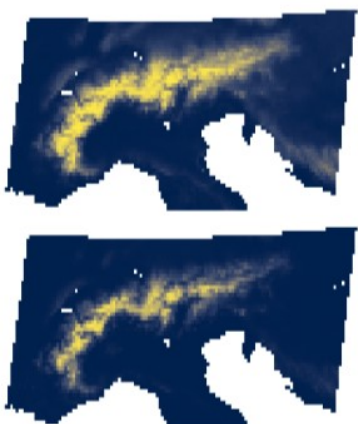

RAW
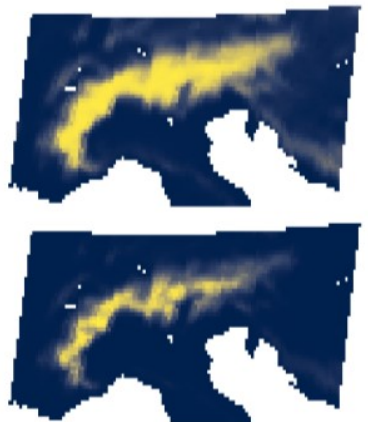

QM
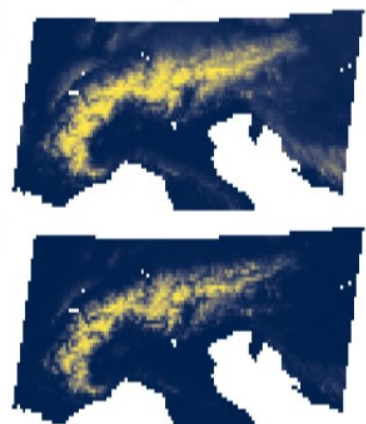

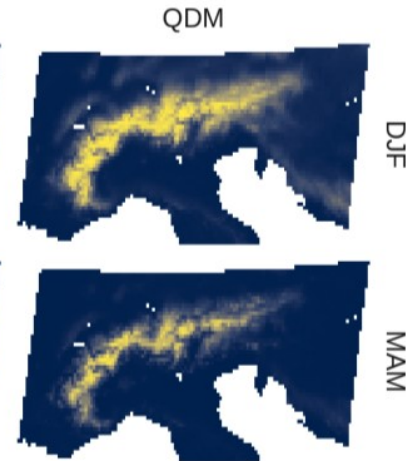

SNC

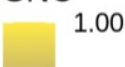

0.75

0.50

0.25

0.00

Figure 4. Average seasonal snow cover fraction (SNC), as observed from remote sensing (OBS) and simulated with the CLMcomCCLM4-8-17 regional climate model driven by CNRM-CERFACS-CNRM-CM5 under the RCP8.5 emission scenario. Abbreviations: remotely sensed observations (OBS), raw climate model output (RAW), quantile mapping (QM), quantile delta mapping (QDM), delta change approach (DC), December-January-February (DJF), March-April-May (MAM). For maps of the other climate models and emission scenarios, see (Matiu, 2021).

Average winter SNC over the whole study domain was $29.3 \%$ for the past (2000-2020) from MODIS observations, and the raw model mean was $30.4 \%$ (24.2, 43.2; model spread). For 2071-2100 under the low emission scenario RCP2.6, SNC decreased by $4.4(2.6,7.9)$ percentage points (pp) based on QDM. Under the high emission scenario RCP8.5 the reduction was $14.3(10.3,19.2)$ pp. Observed past spring SNC was $13.5 \%$, while the raw model mean was $13.0 \%(7.8,21.9)$. Future changes under RCP2.6 were $-2.7(-4.6,0.1)$ pp, while under RCP8.5 changes were $-6.5(-9.2,-4.6) \mathrm{pp}$. The estimates for RCP2.6 are based on a much lower ensemble of only 4 GCM-RCM combinations, compared to 23 for RCP8.5, and thus are less likely to represent model uncertainty well. 
Projected changes until the end of the century depended strongly on elevation, and the strongest reductions in winter SNC were observed between 600 and $2000 \mathrm{~m}$ and in spring above $1000 \mathrm{~m}$ (Figure S4 and S5). Under RCP2.6, winter SNC decreases approximately $7 \mathrm{pp}$ at $1000 \mathrm{~m}$ elevation, while above $2000 \mathrm{~m}$ it's less than $2 \mathrm{pp}$ and the model uncertainty includes no change (Table S3). Under RCP8.5, winter SNC decreases more than 15 pp between 600 and $2000 \mathrm{~m}$ elevation, with strongest changes at 1200 to $1400 \mathrm{~m}$, which amount to $-25.2(-35.0,-17.7) \mathrm{pp}$. In spring under RCP2.6, strongest reductions in SNC were observed at 1400 to $2000 \mathrm{~m}$ with more than $10 \mathrm{pp}$ decreases in SNC. On the other hand, under RCP8.5, reductions in SNC were almost twice as large and remained high also above $2000 \mathrm{~m}$ compared to RCP2.6, where they gradually diminished, for example, at 2400 to $2600 \mathrm{~m}$, changes were $-23.4(-43.5,-5.0)$ under RCP8.5 and $-4.4(-8.8,-0.6)$ under RCP2.6 (Table S4). In addition, a high model uncertainty in projected changes of spring SNC above $2000 \mathrm{~m}$ under RCP8.5 was observed: The model spread ranged from almost no change to an approximate halving of SNC (Figure S4 and Table S4).

This model spread in spring SNC under RCP8.5 is likely caused by the snow schemes in the climate model's land surface schemes in combination with the projected temperature and precipitation changes, which directly affect SWE, and, since SNC is parametrized on SWE, also SNC. Higher uncertainties are expected in spring because potential errors accumulate over the snow season. However, a detailed discussion on snow model processes and uncertainties is beyond the scope of this study, and better addressed in dedicated projects, such as ESM-SnowMIP (Krinner et al., 2018).

An in-depth view of the bias correction results at a single grid cell highlights the main differences between raw climate model SNC and observations as well as between QM and QDM (Figure S6). RCMs have more saturated SNC at both 0 (snow free) and 1 (snow covered) and thus display a more of a fully snow free and fully snow-covered grid cell over time as compared to MODIS. This is likely caused by sub-grid variability, which is prominent in MODIS, since it's based on $250 \mathrm{~m}$ information. The trend-preserving attribute of QDM keeps the distribution of SNC identical between past and future when raw model SNC does not change, e.g., for the fraction of time, where the grid cell is fully snow covered (Fig. S6). In the same situation, QM shows reductions in SNC. Additionally, QM has spurious breaks caused by applying the method monthby-month, but not QDM. While these breaks could be alleviated by applying the bias correction with a moving window approach (e.g. 3-6 months) or using the whole year, QM still suffers from artificial modification of trends, as has been partly shown before for precipitation (Maurer and Pierce, 2014; Maraun, 2013). Consequently, it should be treated with caution for snow cover fraction, too. For the downscaling below, we thus only used results from QDM.

\subsection{Downscaled projections of snow cover duration}

Downscaled projections of high-resolution snow cover duration (SCD) based on low-resolution snow cover fraction (SNC) showed decreases in annual SCD under both emission scenarios, but much stronger under the high emission RCP8.5 
https://doi.org/10.5194/hess-2021-449

Preprint. Discussion started: 23 September 2021

(c) Author(s) 2021. CC BY 4.0 License.
Hydrology and

Earth System

Sciences

Discussions

340 scenarios (Fig. 5). Similar to Section 4.1, changes strongly depended on elevation (Fig. S7), with reductions increasing with elevation (Fig. S8). For example, observed annual SCD averaged over all pixels between 800 and $1000 \mathrm{~m}$ in the study area was on average $48 \mathrm{~d}$ for 2000 to 2020. For 2071-2100 the model mean under RCP2.6 was $32 \mathrm{~d}$ (25, 38; model spread) and $15 \mathrm{~d}(8,21)$ under RCP8.5 (Table S5). At higher elevations of 1800 to $2000 \mathrm{~m}$, SCD decreased from $163 \mathrm{~d}$ to $141 \mathrm{~d}(123$, $155)$ under RCP2.6 and to $98(61,125)$ under RCP8.5, while at 2800 to $3000 \mathrm{~m}$, SCD decreased from $309 \mathrm{~d}$ to $278 \mathrm{~d}(264$,

345 289) under RCP2.6 and to $220(152,236)$ under RCP8.5. In relative terms, these reductions are in the order of 34,13 , and 10 $\%$ under RCP2.6 for 800-1000 m, 1800-2000m, and 2800-3000m, respectively, and 69, 40, and $29 \%$ under RCP8.5.

(a)

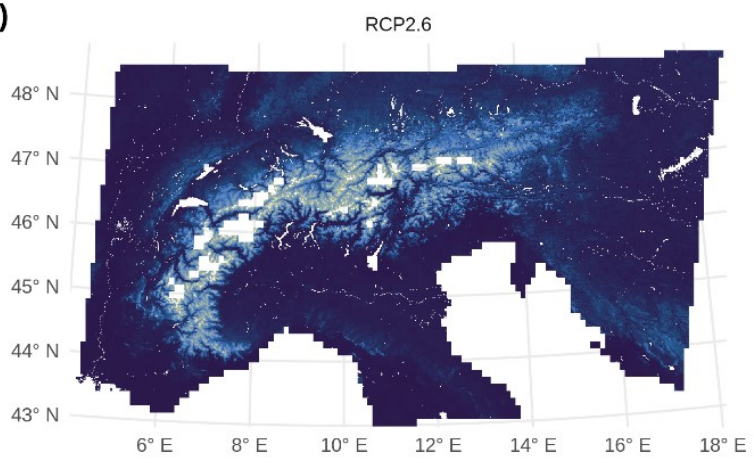

(b)

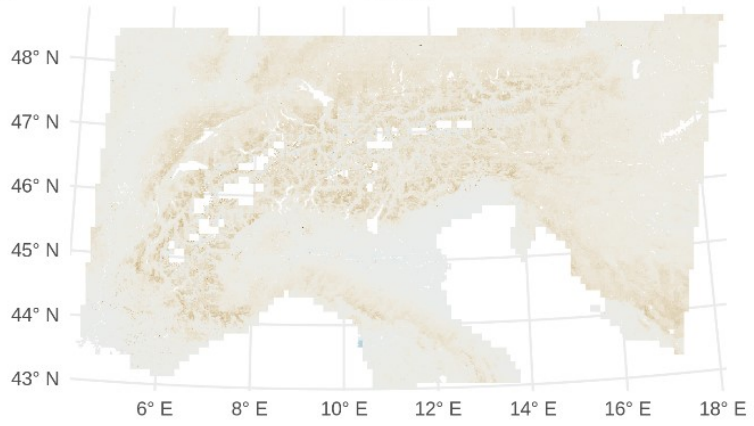

(c)

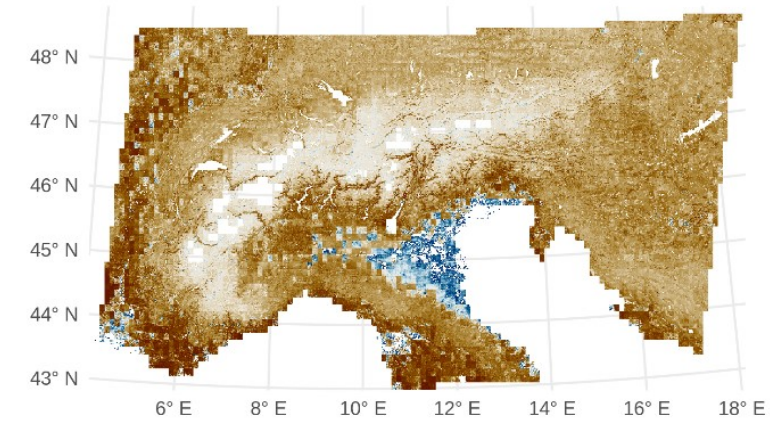

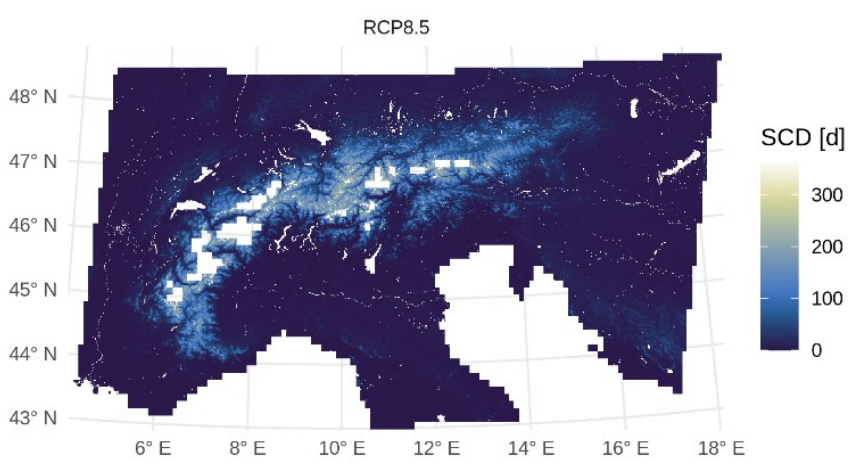

RCP8.5

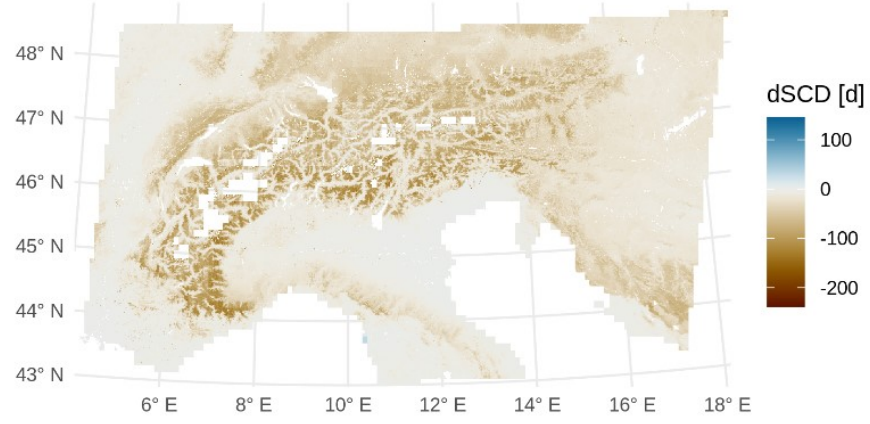

RCP8.5

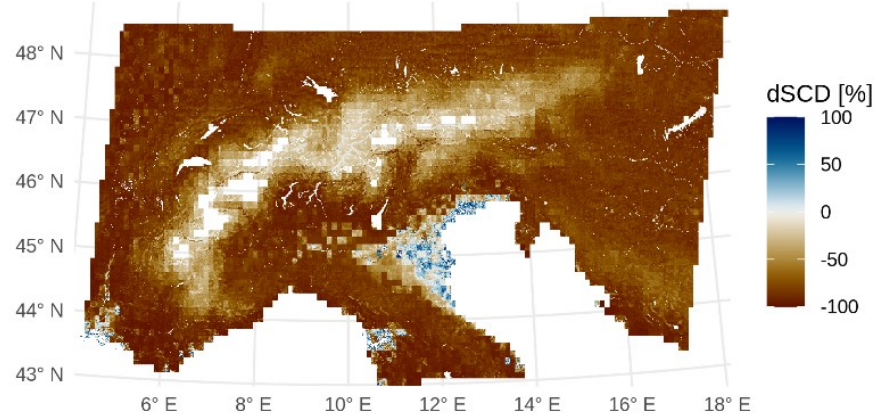


Figure 5. Future 2071-2100 annual snow cover duration (SCD) maps and differences to current observations (dSCD). (a) Downscaled SCD maps for low and high emission scenarios (RCP, representative concentration pathway) based on an ensemble of 4 models for RCP2.6 (regional climate models driven by general circulation models) and 23 models for RCP8.5. Empty areas denote pixels removed because of snow accumulation issues (see methods), glaciers, or water bodies. (b) Differences between (a) and remote sensing observations (Fig. 1c) in absolute day. (c) Relative differences; pixels with $>+100 \%$ difference omitted, because low values of observed SCD caused noise in relative estimates for low SCD (most of the remaining positive changes are for areas with $\mathrm{SCD}<=\mathbf{5} \mathrm{d}$, too).

The European Alps have a prominent north-south climatic divide (Auer et al., 2007), which manifests itself in snow cover duration, too. Taking anomalies of SCD by elevation shows, on average, higher SCD north of the main ridge and lower SCD south (Fig. S9a). These patterns were reproduced in RCMs, too, and changed in the future period: Comparing RCP2.6 to RCP8.5, the north-south gradient in SCD became less strong for lower elevations and more pronounced for higher elevations (Fig. S9). In addition, a stronger relative decline in SCD was observed south and west of the Alps compared to north and east (Fig. 5c) under RCP2.6. An analysis of station snow depth and SCD trends over the last five decades in the Alps similarly showed stronger declines south than north (Matiu et al., 2021). Consequently, this trend might continue in the future given the findings in this study.

The average downscaling uncertainty (bias and error, see Sec. 3.2, Fig. S3) was much lower than model spread and future change estimates. Thus, the largest part of uncertainty of future projections was less because of the downscaling method, but more caused by the spread in GCM forcing together with RCM snow schemes. Since there is no single "best" climate model (Vautard et al., n.d.) and no single best snow model (Etchevers et al., 2004; Rutter et al., 2009; Menard et al., 2021), we conclude it is safe to take model spread as representative of model uncertainty for future projections. However, the negative bias from downscaling caused future estimates to be also negatively biased as compared to estimates from bias correction only (Fig. S10). For example, the average difference over all low-resolution grid cells in future annual SNC under RCP8.5 between the bias corrected ensemble mean and an upscaled SNC after downscaling was $-1.4 \mathrm{pp}$, which corresponds to $-4.9 \mathrm{~d}$. The employed statistical downscaling method extrapolates information beyond the elevation coverage of the RCMs. At $0.11^{\circ}$, and not considering the pixels with snow accumulation, the highest grid cell from low-resolution RCMs was at approximately $3000 \mathrm{~m}$, which contained single high-resolution pixels with elevations up to $4105 \mathrm{~m}$. The downscaled estimates above $3000 \mathrm{~m}$ thus should be treated with caution, even though the observed stronger reductions at elevations above $3000 \mathrm{~m}$ from downscaling are similar to the results of the simulations from a high-resolution RCM, which explicitly resolved elevations up to 3500/4000 m (Lüthi et al., 2019).

A benefit of the proposed downscaling approach is that is based on the truly local features, which were derived from 20 years of observations. In contrast to the final imputation step of SNCp50, which is based on a simple elevational dependence of snow cover, which can, in theory, directly be estimated from a low-resolution RCM signal. At least, the initial derivation 385 of SNCp50 and the first imputation step can be assumed to provide downscaled estimates based on local features, while the results of pixels that were subject to the final elevation imputation are more generalized. On the other hand, the pixel-by- 
pixel approach introduced artefacts at the low-resolution pixel boundaries (e.g., Fig. 5c). For the future, other downscaling techniques could be explored, such as analogue based or spatially explicit downscaling approaches based on principial components analysis.

One assumption in the downscaling is that the remotely sensed observations from MODIS are true, but these also have errors and noise. Generally, accuracies in determining binary snow information (snow or land) are largely above 90\% for MODIS (Parajka and Blöschl, 2006; Gafurov and Bárdossy, 2009). However, considerable uncertainty and lower accuracies were found for forested areas and locations affected by terrain shading (Notarnicola et al., 2013b). Specific to this study is the use of a cloud filtered product, which provides gap-free spatiotemporal series. The used filtering techniques resulted in only slightly lower overall accuracies of $91.5 \%$ compared to $93 \%$ for the original images (Matiu et al., 2020a). However, the spatial and temporal filters that were applied to remove clouds might miss short snow episodes in low elevations and are difficult to validate in higher elevations, because of low ground station coverage. A pixel with erroneous information from MODIS will translate to an erroneous downscaled pixel, so relying on single pixels without consulting the spatial surrounding is not advised.

400 In addition, the downscaling assumes no land cover change, which might be problematic, for example, where the tree line increases, and forests migrate to higher elevation. This comes on top to the already challenging estimation of snow cover fraction from remote sensing for forested areas. Under a warming climate, complex vegetation-snow interactions can occur, such as opposing effects on the interception and subsequent melting of snow in forests (DeBeer et al., 2021).

\subsection{Comparison of downscaling to a dedicated snow model}

For the Ötztal Alps region in Austria (Fig. 1), we compared results from bias correction and downscaling of RCM snow cover fraction (SNC) to running a dedicated snow model (AMUNDSEN), which has been forced by meteorology from RCMs. For the past period (2000-2020), the downscaling resulted in lower SNC than AMUNDSEN up to approximately $2000 \mathrm{~m}$, similar SNC from 2100 to 2600m, and higher SNC for elevations above $2700 \mathrm{~m}$ (Fig. 6 and S11). However, elevations above $2700 \mathrm{~m}$ are challenging to compare, since many pixels were removed from bias correction and downscaling at these elevations because of snow accumulation issues and glaciers, while AMUNDSEN resolved the whole domain and explicitly considered ice-snow transitions. Consequently, comparisons above $2700 \mathrm{~m}$ are not based on the same pixels.

For the future period (2071-2100) under RCP8.5, estimates of SNC agreed between bias correction, downscaling, and AMUNDSEN for elevations from 1800 to $2800 \mathrm{~m}$, considering model ensemble uncertainty. But strong disagreement was

415 observed above and below. For elevations below $1500 \mathrm{~m}$, AMUNDSEN had much lower SNC than downscaling, for example, at $1000 \mathrm{~m}$, AMUNDSEN showed 5.8 (1.5, 12.3) \% SNC but downscaling resulted in 13.7 (12.5, 14.2$) \%$.

The elevation gradient of projected changes under RCP8.5 differed substantially between AMUNDSEN and downscaling (Fig. S12). While AMUNDSEN showed mostly constant change across elevation, with slightly stronger decreases between 1500 and $2000 \mathrm{~m}$ under RCP8.5, the bias corrected or downscaled SNC from RCM showed a strong elevational gradient, 
such that decreases in SNC became stronger with increasing elevation. This elevation gradient in the RCM signal was also present at the whole study region scale (Fig. S10b), but there downscaling showed consistently stronger decreases than bias correction only.

We assume this different behavior across elevations might be partly caused by elevation dependent warming, which implies stronger warming rates with increasing elevations, and which was observed in GCMs and RCMs at varying resolutions (Palazzi et al., 2019; Kotlarski et al., 2015; Lüthi et al., 2019). This might explain the elevation gradient in SNC changes based on RCM data. While the projections from AMUNDSEN were also based on RCM meteorology, they underwent significant post-processing, including bias correction, spatial interpolation, and temporal disaggregation. Given this study's setup, it's not possible to disentangle how climate change signals and uncertainties flow through the modelling chain of both approaches with their different statistical post-processing and physical models. But we propose that such an assessment would be beneficial for highlighting important aspects of the modelling uncertainty of future mountain snow cover. A related issue is that for bias correction of SNC, RCMs caused more of the overall variability than their driving GCMs, while in Hanzer et al. (2018), it was the opposite.

A further cause of the strong differences in SNC changes especially at lower elevations might be due to the consideration of forest snow processes in the AMUNDSEN simulations, where a canopy submodule accounts for the interception of snow by the trees - from where the snow can subsequently sublimate or melt without reaching the ground - as well as the modification of the meteorological variables for sub-canopy conditions; for details see (Strasser et al., 2011). As the AMUNDSEN SNC results considered in this study only correspond to snow on the ground, this can cause differences with the RCM-based SNC changes, considering the large proportion of forested areas in the affected elevation bands $(61 \%$ forest coverage for elevations $<2000 \mathrm{~m}$ compared to only $2 \%$ for elevations $>=2000 \mathrm{~m}$ ).

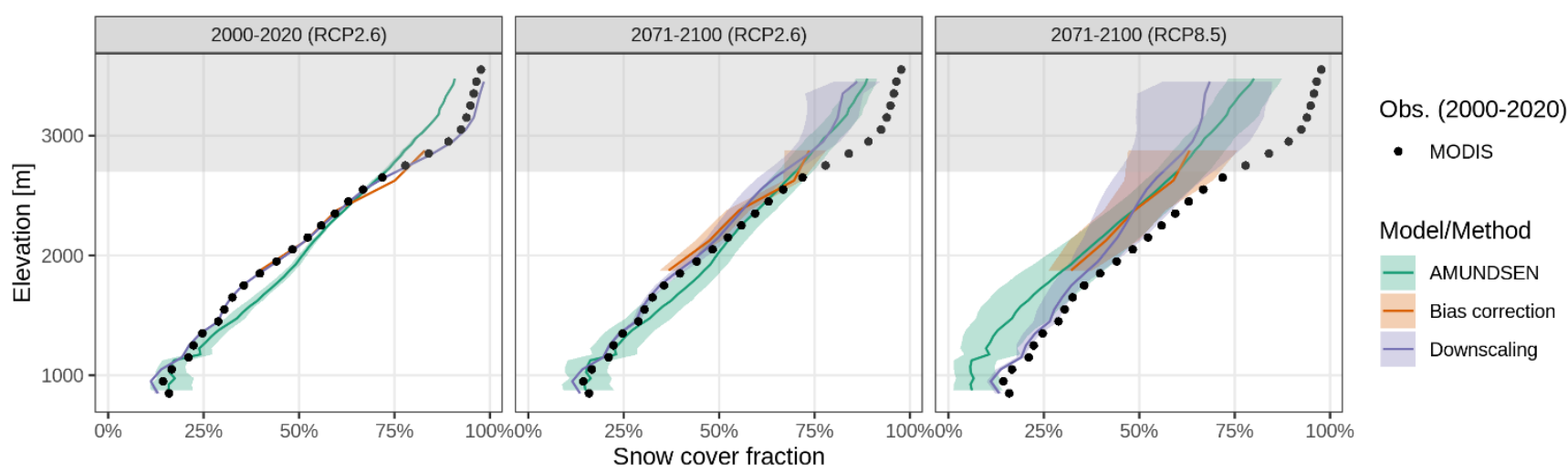

Figure 6. Past and future snow cover fraction (SNC) for the Ötztal Alps region by elevation band (see Fig. 1 for location and extent of the catchment). Black points denote observed SNC from 20 years of MODIS remote sensing. Colored lines and transparent regions denote model means and model spread from running a snow and hydroclimatological model (AMUNDSEN), forced by downscaled meteorology from regional climate models (RCMs), from bias corrected SNC from RCMs, and from downscaled SNC 
from RCMs. Shaded grey area (above $2700 \mathrm{~m}$ ) indicates elevations, where $>\mathbf{2 0} \%$ of the pixels entering the average per elevation band were removed from MODIS and Downscaling but remained included in AMUNDSEN: these consist of glacierized pixels or pixels subject to snow accumulation in RCMs, while AMUNDSEN resolved the whole domain.

To conclude the comparison of bias correction and downscaling to using a dedicated snow model, Table 1 offers an overview of their main features. Both approaches enable to assess climate model uncertainty by using model ensembles, but both suffer from the potential need to extrapolate the RCM signal (surface meteorology or snow cover) beyond its elevation coverage. The main differences between the two approaches are in their spatial extent, spatial detail, and the representation of snow and ice processes.

Table 1. Non-exhaustive comparison of benefits (denoted with a + ) and drawbacks (denoted with a - ) of the two methods considered in this study. Abbreviations: regional climate model (RCM), snow cover fraction (SNC).

\begin{tabular}{ll}
\multicolumn{1}{c}{ Dedicated model forced by RCM meteorology } & \multicolumn{1}{c}{ Bias correction (and downscaling) of RCM SNC } \\
\hline + Strong local (topographic) detail possible & - Limited by RCM resolution; artefacts at grid cell boundaries \\
+ Detailed representation of snow and ice processes & - Limited by adequacy of RCM snow scheme \\
+ All snow cover variables (water equivalents, depths, area covered) & - Only snow cover fraction \\
- Limited spatial extent & + Applicable at large spatial scales \\
- Decoupling of surface meteorology and snow cover in climate & + Consistent climate change signal of surface meteorology with \\
change signal & snow cover \\
(-) Requires extensive snow modelling experience & $(+)$ Mostly statistical and computational skills required
\end{tabular}

Previous studies on the future of snow cover in the European Alps found differing trend magnitudes, but quantitative comparisons are hampered by different study extents and emission scenarios.

Marty et al. (2017) found decreases of snow cover duration until the end of the century from 100 to $14-18 \mathrm{~d}$ at $1000 \mathrm{~m}, 157$ to $49 \mathrm{~d}$ at $1500 \mathrm{~m}$, and 254 to $163 \mathrm{~d}$ at $2700 \mathrm{~m}$ (cf. Table S2 in Marty et al. (2017)), while here we found 58 to $22 \mathrm{~d}$, 101 to

$46551 \mathrm{~d}$, and 274 to $193 \mathrm{~d}$, at the respective altitudes (Table S5). Their estimates were based on the Alpine3D snow model for subregions of Switzerland, forced by RCM meteorology from the ENSEMBLES project, under the A2 emission scenario, which has less GHG concentrations at the end of the century compared to the RCP8.5 in this study. The differences in the reference values by elevation likely originate from the different study extent, while the differences in change estimates might partly be caused by different reference periods for the past.

470 Lüthi et al. (2019) found a decrease of 60\% in SWE and two months short snow cover duration by analyzing one regional climate model at $2 \mathrm{~km}$ spacing over the Alpine region under RCP8.5, while we observed a 49\% reduction in SNC and an average reduction of $25 \mathrm{~d}$ in SCD. Trend differences might be explained by the fact that domain averages strongly depend on the investigated domain, and Lüthi et al. (2019) have a different extent of Alpine region compared to this study. In addition, 
their domain includes much higher elevations due to the lower horizontal spacing, and the higher elevations showed stronger reductions in snow cover.

\section{Conclusion}

Bias correction of snow cover fraction from RCMs using aggregated MODIS remote sensing observations offers a promising approach to evaluate future changes of snow cover fraction in mountain areas under a climate model ensemble view. While limited by the resolution of RCMs, it offers consistent large-scale patterns of snow cover fraction for the past and future, and it is potentially applicable on a global scale. Consequently, it might be a viable alternative in remote or less monitored areas. While snow cover fraction is probably not a priority for climate modelling groups to be made available, the proposed bias correction could benefit from an increasing ensemble of climate models being present. Regarding bias corrections methods, trend-preserving approaches, such as delta change or quantile delta mapping, were found superior to quantile mapping for snow cover fraction.

485 For the study region, which is approximately the Greater Alpine Region, results showed an overall reduction in snow cover fraction for 2071-2100 compared to 2000-2020 of $17 \%$ for RCP2.6 and $49 \%$ under RCP8.5. However, strong elevational and seasonal dependencies of changes were found (Table S3 and S4, Fig. S5), with stronger decreases at middle elevations in winter (500-2000 m) and higher elevations in spring (above $1500 \mathrm{~m}$ ). In addition, spatial patterns of change emerged, with stronger relative decreases in the south and west compared to north and east (Fig. 5), which are consistent to past trends of station observations of snow depth (Matiu et al., 2021).

The downscaling of RCM SNC with high-resolution MODIS observations falls under an "experimental" label. It suffers from many inadequacies, such as snow accumulation in RCMs, noise in observations, and is likely inappropriate for glacierized areas. However, it can provide auxiliary and high spatial resolution information while accounting for climate model uncertainty. The discrepancies to results from a dedicated snow model require further research before a final recommendation can be given. Potential usages of the downscaled information include hydrological studies or glacier modelling studies that require snow line information. They might help in determining winter sport reliability, even though future assessments that do not account for technical snow are most likely not very useful (Spandre et al., 2019; Morin et al., 2021). Finally, downscaling approaches should be kept in mind considering the new generation of soon to be available highresolution (at or below $2 \mathrm{~km}$ ) RCMs, for example, from CORDEX flagship pilot studies, together with long-term remote sensing observations at tens of meters scale, such as harmonized Landsat Sentinel series. 
https://doi.org/10.5194/hess-2021-449

Preprint. Discussion started: 23 September 2021

(C) Author(s) 2021. CC BY 4.0 License.

(c) (P)
Hydrology and

Earth System

Sciences

Discussions

\section{Code and data availability}

All code to perform the analysis is available in a public repository (Matiu, 2021). The repository also holds final processed data of the snow cover duration climatologies from MODIS, as well as single GCM-RCM maps from bias correction and downscaling. The input data is not shared, because of its large size. The RCM data is available for non-commercial use after registration (https://cordex.org/data-access/). For access to the MODIS observations, see Matiu et al. (2020a). The AMUNDSEN data is available from FH upon request.

\section{Author contribution}

MM defined the study concept, performed the formal analysis, and wrote the original draft. MM and FH were involved in data curation. Paper review and editing were performed by MM and FH.

\section{Competing interests}

The authors declare that they have no conflict of interest.

\section{Acknowledgements}

This project has received funding from the European Union's Horizon 2020 research and innovation programme under the Marie Sklodowska-Curie grant agreement no. 795310.

We acknowledge the World Climate Research Programme's Working Group on Regional Climate, and the Working Group on Coupled Modelling, former coordinating body of CORDEX and responsible panel for CMIP5. We also thank the climate modelling groups for producing and making available their model output. We also acknowledge the Earth System Grid Federation infrastructure an international effort led by the U.S. Department of Energy's Program for Climate Model Diagnosis and Intercomparison, the European Network for Earth System Modelling and other partners in the Global Organisation for Earth System Science Portals (GO-ESSP).

We thank Valentina Premier for assistance and discussion regarding the downscaling procedure, and Marc Zebisch for general discussions. 


\section{References}

Auer, I., Böhm, R., Jurkovic, A., Lipa, W., Orlik, A., Potzmann, R., Schöner, W., Ungersböck, M., Matulla, C., Briffa, K., Jones, P., Efthymiadis, D., Brunetti, M., Nanni, T., Maugeri, M., Mercalli, L., Mestre, O., Moisselin, J.-M., Begert, M., Müller-Westermeier, G., Kveton, V., Bochnicek, O., Stastny, P., Lapin, M., Szalai, S., Szentimrey, T., Cegnar, T., Dolinar, M., Gajic-Capka, M., Zaninovic, K., Majstorovic, Z., and Nieplova, E.: HISTALP - historical instrumental climatological surface time series of the Greater Alpine Region, 27, 17-46, https://doi.org/10.1002/joc.1377, 2007.

Brun, E., Martin, E., Simon, V., Gendre, C., and Coleou, C.: An Energy and Mass Model of Snow Cover Suitable for Operational Avalanche Forecasting, 35, 333-342, https://doi.org/10.3189/S0022143000009254, 1989.

Cannon, A. J.: Multivariate quantile mapping bias correction: an N-dimensional probability density function transform for

Cannon, A. J., Sobie, S. R., and Murdock, T. Q.: Bias Correction of GCM Precipitation by Quantile Mapping: How Well Do Methods Preserve Changes in Quantiles and Extremes?, J. Climate, 28, 6938-6959, https://doi.org/10.1175/JCLI-D-14$00754.1,2015$.

CH2018: CH2018 - Climate Scenarios for Switzerland, Technical Report, National Centre for Climate Services, Zurich, 2018.

Coppola, E., Nogherotto, R., Ciarlo', J. M., Giorgi, F., Meijgaard, E. van, Kadygrov, N., Iles, C., Corre, L., Sandstad, M., Somot, S., Nabat, P., Vautard, R., Levavasseur, G., Schwingshackl, C., Sillmann, J., Kjellström, E., Nikulin, G., Aalbers, E., Lenderink, G., Christensen, O. B., Boberg, F., Sørland, S. L., Demory, M.-E., Bülow, K., Teichmann, C., Warrach-Sagi, K., and Wulfmeyer, V.: Assessment of the European Climate Projections as Simulated by the Large EURO-CORDEX Regional and Global Climate Model Ensemble, 126, e2019JD032356, https://doi.org/10.1029/2019JD032356, 2021.

DeBeer, C. M., Wheater, H. S., Pomeroy, J. W., Barr, A. G., Baltzer, J. L., Johnstone, J. F., Turetsky, M. R., Stewart, R. E., Hayashi, M., van der Kamp, G., Marshall, S., Campbell, E., Marsh, P., Carey, S. K., Quinton, W. L., Li, Y., Razavi, S., Berg, A., McDonnell, J. J., Spence, C., Helgason, W. D., Ireson, A. M., Black, T. A., Elshamy, M., Yassin, F., Davison, B., Howard, A., Thériault, J. M., Shook, K., Demuth, M. N., and Pietroniro, A.: Summary and synthesis of Changing Cold

555 Regions Network (CCRN) research in the interior of western Canada - Part 2: Future change in cryosphere, vegetation, and hydrology, 25, 1849-1882, https://doi.org/10.5194/hess-25-1849-2021, 2021.

Dong, C. and Menzel, L.: Producing cloud-free MODIS snow cover products with conditional probability interpolation and meteorological data, Remote Sensing of Environment, 186, 439-451, https://doi.org/10.1016/j.rse.2016.09.019, 2016.

Etchevers, P., Martin, E., Brown, R., Fierz, C., Lejeune, Y., Bazile, E., Boone, A., Dai, Y.-J., Essery, R., Fernandez, A., 560 Gusev, Y., Jordan, R., Koren, V., Kowalczyk, E., Nasonova, N. O., Pyles, R. D., Schlosser, A., Shmakin, A. B., Smirnova, T. G., Strasser, U., Verseghy, D., Yamazaki, T., and Yang, Z.-L.: Validation of the energy budget of an alpine snowpack simulated by several snow models (Snow MIP project), 38, 150-158, https://doi.org/10.3189/172756404781814825, 2004.

EURO-CORDEX $\quad$ Errata: https://docs.google.com/spreadsheets/d/1Vcob7VlE4H98g0IdMzdy5Ae4YWU01RktI1 mPneibXM/edit?usp=embed_facebook, last access: 23 July 2021.

565 Fugazza, D., Manara, V., Senese, A., Diolaiuti, G., and Maugeri, M.: Snow Cover Variability in the Greater Alpine Region in the MODIS Era (2000-2019), 13, 2945, https://doi.org/10.3390/rs13152945, 2021.

Gafurov, A. and Bárdossy, A.: Cloud removal methodology from MODIS snow cover product, 13, 1361-1373, https://doi.org/10.5194/hess-13-1361-2009, 2009. 
Gudmundsson, L., Bremnes, J. B., Haugen, J. E., and Engen-Skaugen, T.: Technical Note: Downscaling RCM precipitation to the station scale using statistical transformations \&ndash; a comparison of methods, 16, 3383-3390, https://doi.org/10.5194/hess-16-3383-2012, 2012.

Hanzer, F., Förster, K., Nemec, J., and Strasser, U.: Projected cryospheric and hydrological impacts of 21st century climate change in the Ötztal Alps (Austria) simulated using a physically based approach, 22, 1593-1614, https://doi.org/10.5194/hess-22-1593-2018, 2018.

575 Hock, R.: Temperature index melt modelling in mountain areas, Journal of Hydrology, 282, 104-115, https://doi.org/10.1016/S0022-1694(03)00257-9, 2003.

Huss, M., Bookhagen, B., Huggel, C., Jacobsen, D., Bradley, R. S., Clague, J. J., Vuille, M., Buytaert, W., Cayan, D. R., Greenwood, G., Mark, B. G., Milner, A. M., Weingartner, R., and Winder, M.: Toward mountains without permanent snow and ice, 5, 418-435, https://doi.org/10.1002/2016EF000514, 2017.

580 Immerzeel, W. W., Lutz, A. F., Andrade, M., Bahl, A., Biemans, H., Bolch, T., Hyde, S., Brumby, S., Davies, B. J., Elmore, A. C., Emmer, A., Feng, M., Fernández, A., Haritashya, U., Kargel, J. S., Koppes, M., Kraaijenbrink, P. D. A., Kulkarni, A. V., Mayewski, P. A., Nepal, S., Pacheco, P., Painter, T. H., Pellicciotti, F., Rajaram, H., Rupper, S., Sinisalo, A., Shrestha, A. B., Viviroli, D., Wada, Y., Xiao, C., Yao, T., and Baillie, J. E. M.: Importance and vulnerability of the world's water towers, 577, 364-369, https://doi.org/10.1038/s41586-019-1822-y, 2020.

585 Kotlarski, S., Lüthi, D., and Schär, C.: The elevation dependency of 21st century European climate change: an RCM ensemble perspective, International Journal of Climatology, 35, 3902-3920, https://doi.org/10.1002/joc.4254, 2015.

Krähenmann, S., Walter, A., and Lara Klippel: Statistische Aufbereitung von Klimaprojektionen: Downscaling und multivariate Bias-Adjustierung Im Rahmen des BMVI-Expertennetzwerkes entwickelte Verfahren zum Postprocessing von Klimamodelldaten, 2021.

590 Krinner, G., Derksen, C., Essery, R., Flanner, M., Hagemann, S., Clark, M., Hall, A., Rott, H., Brutel-Vuilmet, C., Kim, H., Ménard, C. B., Mudryk, L., Thackeray, C., Wang, L., Arduini, G., Balsamo, G., Bartlett, P., Boike, J., Boone, A., Chéruy, F., Colin, J., Cuntz, M., Dai, Y., Decharme, B., Derry, J., Ducharne, A., Dutra, E., Fang, X., Fierz, C., Ghattas, J., Gusev, Y., Haverd, V., Kontu, A., Lafaysse, M., Law, R., Lawrence, D., Li, W., Marke, T., Marks, D., Ménégoz, M., Nasonova, O., Nitta, T., Niwano, M., Pomeroy, J., Raleigh, M. S., Schaedler, G., Semenov, V., Smirnova, T. G., Stacke, T., Strasser, U.,

595 Svenson, S., Turkov, D., Wang, T., Wever, N., Yuan, H., Zhou, W., and Zhu, D.: ESM-SnowMIP: assessing snow models and quantifying snow-related climate feedbacks, 11, 5027-5049, https://doi.org/10.5194/gmd-11-5027-2018, 2018.

Largeron, C., Dumont, M., Morin, S., Boone, A., Lafaysse, M., Metref, S., Cosme, E., Jonas, T., Winstral, A., and Margulis, S. A.: Toward Snow Cover Estimation in Mountainous Areas Using Modern Data Assimilation Methods: A Review, Front. Earth Sci., 8, https://doi.org/10.3389/feart.2020.00325, 2020.

600 Li, M., Zhu, X., Li, N., and Pan, Y.: Gap-Filling of a MODIS Normalized Difference Snow Index Product Based on the Similar Pixel Selecting Algorithm: A Case Study on the Qinghai-Tibetan Plateau, 12, 1077, https://doi.org/10.3390/rs12071077, 2020.

Lüthi, S., Ban, N., Kotlarski, S., Steger, C. R., Jonas, T., and Schär, C.: Projections of Alpine Snow-Cover in a HighResolution Climate Simulation, 10, 463, https://doi.org/10.3390/atmos10080463, 2019.

605 Maraun, D.: Bias Correction, Quantile Mapping, and Downscaling: Revisiting the Inflation Issue, 26, 2137-2143, https://doi.org/10.1175/JCLI-D-12-00821.1, 2013. 
Marty, C., Schlögl, S., Bavay, M., and Lehning, M.: How much can we save? Impact of different emission scenarios on future snow cover in the Alps, The Cryosphere, 11, 517-529, https://doi.org/10.5194/tc-11-517-2017, 2017.

Marzeion, B., Kaser, G., Maussion, F., and Champollion, N.: Limited influence of climate change mitigation on short-term glacier mass loss, 8, 305-308, https://doi.org/10.1038/s41558-018-0093-1, 2018.

Matiu, M.: Bias corrected and downscaled snow cover fraction from EURO-CORDEX RCMs for the Greater Alpine Region (version v1.0) [Data set], https://doi.org/10.5281/zenodo.5266360, 2021.

Matiu, M., Jacob, A., and Notarnicola, C.: Daily MODIS Snow Cover Maps for the European Alps from 2002 onwards at $250 \mathrm{~m}$ Horizontal Resolution Along with a Nearly Cloud-Free Version, 5, 1, https://doi.org/10.3390/data5010001, 2020a.

615 Matiu, M., Petitta, M., Notarnicola, C., and Zebisch, M.: Evaluating Snow in EURO-CORDEX Regional Climate Models with Observations for the European Alps: Biases and Their Relationship to Orography, Temperature, and Precipitation Mismatches, 11, 46, https://doi.org/10.3390/atmos11010046, 2020b.

Matiu, M., Crespi, A., Bertoldi, G., Carmagnola, C. M., Marty, C., Morin, S., Schöner, W., Cat Berro, D., Chiogna, G., De Gregorio, L., Kotlarski, S., Majone, B., Resch, G., Terzago, S., Valt, M., Beozzo, W., Cianfarra, P., Gouttevin, I., Marcolini,

620 G., Notarnicola, C., Petitta, M., Scherrer, S. C., Strasser, U., Winkler, M., Zebisch, M., Cicogna, A., Cremonini, R., Debernardi, A., Faletto, M., Gaddo, M., Giovannini, L., Mercalli, L., Soubeyroux, J.-M., Sušnik, A., Trenti, A., Urbani, S., and Weilguni, V.: Observed snow depth trends in the European Alps: 1971 to 2019, 15, 1343-1382, https://doi.org/10.5194/tc-15-1343-2021, 2021.

Maurer, E. P. and Pierce, D. W.: Bias correction can modify climate model simulated precipitation changes without adverse effect on the ensemble mean, 18, 915-925, https://doi.org/10.5194/hess-18-915-2014, 2014.

Menard, C. B., Essery, R., Krinner, G., Arduini, G., Bartlett, P., Boone, A., Brutel-Vuilmet, C., Burke, E., Cuntz, M., Dai, Y., Decharme, B., Dutra, E., Fang, X., Fierz, C., Gusev, Y., Hagemann, S., Haverd, V., Kim, H., Lafaysse, M., Marke, T., Nasonova, O., Nitta, T., Niwano, M., Pomeroy, J., Schädler, G., Semenov, V. A., Smirnova, T., Strasser, U., Swenson, S., Turkov, D., Wever, N., and Yuan, H.: Scientific and Human Errors in a Snow Model Intercomparison, 102, E61-E79, https://doi.org/10.1175/BAMS-D-19-0329.1, 2021.

Morán-Tejeda, E., Lorenzo-Lacruz, J., López-Moreno, J. I., Rahman, K., and Beniston, M.: Streamflow timing of mountain rivers in Spain: Recent changes and future projections, Journal of Hydrology, 517, 1114-1127, https://doi.org/10.1016/j.jhydrol.2014.06.053, 2014.

Morin, S., Samacoïts, R., François, H., Carmagnola, C. M., Abegg, B., Demiroglu, O. C., Pons, M., Soubeyroux, J.-M., 635 Lafaysse, M., Franklin, S., Griffiths, G., Kite, D., Hoppler, A. A., George, E., Buontempo, C., Almond, S., Dubois, G., and Cauchy, A.: Pan-European meteorological and snow indicators of climate change impact on ski tourism, Climate Services, 22, 100215, https://doi.org/10.1016/j.cliser.2021.100215, 2021.

Notarnicola, C., Duguay, M., Moelg, N., Schellenberger, T., Tetzlaff, A., Monsorno, R., Costa, A., Steurer, C., and Zebisch, M.: Snow Cover Maps from MODIS Images at $250 \mathrm{~m}$ Resolution, Part 1: Algorithm Description, 5, 110-126, https://doi.org/10.3390/rs5010110, 2013a.

Notarnicola, C., Duguay, M., Moelg, N., Schellenberger, T., Tetzlaff, A., Monsorno, R., Costa, A., Steurer, C., and Zebisch, M.: Snow Cover Maps from MODIS Images at $250 \mathrm{~m}$ Resolution, Part 2: Validation, 5, 1568-1587, https://doi.org/10.3390/rs5041568, 2013b. 
Palazzi, E., Mortarini, L., Terzago, S., and von Hardenberg, J.: Elevation-dependent warming in global climate model simulations at high spatial resolution, Clim Dyn, 52, 2685-2702, https://doi.org/10.1007/s00382-018-4287-z, 2019.

Parajka, J. and Blöschl, G.: Validation of MODIS snow cover images over Austria, 10, 679-689, https://doi.org/10.5194/hess-10-679-2006, 2006.

Premier, V., Marin, C., Steger, S., Notarnicola, C., and Bruzzone, L.: A novel approach based on a hierarchical multiresolution analysis of optical time series to reconstruct the daily high-resolution snow cover area, IEEE J. Sel. Top. Appl.

Earth Observations Remote Sensing, 1-1, https://doi.org/10.1109/JSTARS.2021.3103585, 2021.

Räisänen, J. and Eklund, J.: 21st Century changes in snow climate in Northern Europe: a high-resolution view from ENSEMBLES regional climate models, Clim Dyn, 38, 2575-2591, https://doi.org/10.1007/s00382-011-1076-3, 2012.

RGI Consortium: Randolph Glacier Inventory - A Dataset of Global Glacier Outlines: Version 6.0: Technical Report, Global Land Ice Measurements from Space, Colorado, USA, Digital Media, https://doi.org/10.7265/N5-RGI-60, 2017.

655 Rutter, N., Essery, R., Pomeroy, J., Altimir, N., Andreadis, K., Baker, I., Barr, A., Bartlett, P., Boone, A., Deng, H., Douville, H., Dutra, E., Elder, K., Ellis, C., Feng, X., Gelfan, A., Goodbody, A., Gusev, Y., Gustafsson, D., Hellström, R., Hirabayashi, Y., Hirota, T., Jonas, T., Koren, V., Kuragina, A., Lettenmaier, D., Li, W.-P., Luce, C., Martin, E., Nasonova, O., Pumpanen, J., Pyles, R. D., Samuelsson, P., Sandells, M., Schädler, G., Shmakin, A., Smirnova, T. G., Stähli, M., Stöckli, R., Strasser, U., Su, H., Suzuki, K., Takata, K., Tanaka, K., Thompson, E., Vesala, T., Viterbo, P., Wiltshire, A., 660 Xia, K., Xue, Y., and Yamazaki, T.: Evaluation of forest snow processes models (SnowMIP2), 114, https://doi.org/10.1029/2008JD011063, 2009.

Spandre, P., François, H., Verfaillie, D., Pons, M., Vernay, M., Lafaysse, M., George, E., and Morin, S.: Winter tourism under climate change in the Pyrenees and the French Alps: relevance of snowmaking as a technical adaptation, 13, 13251347, https://doi.org/10.5194/tc-13-1325-2019, 2019.

665 Steger, C., Kotlarski, S., Jonas, T., and Schär, C.: Alpine snow cover in a changing climate: a regional climate model perspective, Clim Dyn, 41, 735-754, https://doi.org/10.1007/s00382-012-1545-3, 2013.

Strasser, U.: Modelling of the mountain snow cover in the Berchtesgaden National Park, Berchtesgaden National Park, Berchtesgaden, 2008.

Strasser, U., Warscher, M., and Liston, G. E.: Modeling Snow-Canopy Processes on an Idealized Mountain, J. Hydrometeorol., 12, 663-677, https://doi.org/10.1175/2011JHM1344.1, 2011.

Terzago, S., Hardenberg, J. von, Palazzi, E., and Provenzale, A.: Snow water equivalent in the Alps as seen by gridded data sets, CMIP5 and CORDEX climate models, 11, 1625-1645, https://doi.org/10.5194/tc-11-1625-2017, 2017.

Thackeray, C. W., Qu, X., and Hall, A.: Why Do Models Produce Spread in Snow Albedo Feedback?, 45, 6223-6231, https://doi.org/10.1029/2018GL078493, 2018.

675 Vautard, R., Kadygrov, N., Iles, C., Boberg, F., Buonomo, E., Bülow, K., Coppola, E., Corre, L., Meijgaard, E. van, Nogherotto, R., Sandstad, M., Schwingshackl, C., Somot, S., Aalbers, E., Christensen, O. B., Ciarlò, J. M., Demory, M.-E., Giorgi, F., Jacob, D., Jones, R. G., Keuler, K., Kjellström, E., Lenderink, G., Levavasseur, G., Nikulin, G., Sillmann, J., Solidoro, C., Sørland, S. L., Steger, C., Teichmann, C., Warrach-Sagi, K., and Wulfmeyer, V.: Evaluation of the large EURO-CORDEX regional climate model ensemble, n/a, e2019JD032344, https://doi.org/10.1029/2019JD032344, n.d. 
https://doi.org/10.5194/hess-2021-449

Preprint. Discussion started: 23 September 2021

(c) Author(s) 2021. CC BY 4.0 License.

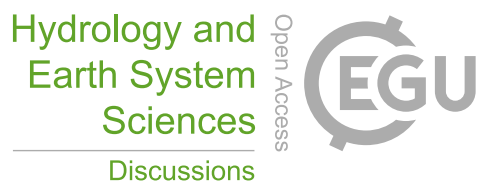

680 Wallace, B. and Minder, J. R.: The impact of snow loss and soil moisture on convective precipitation over the Rocky Mountains under climate warming, Clim Dyn, https://doi.org/10.1007/s00382-020-05622-7, 2021.

Warscher, M., Wagner, S., Marke, T., Laux, P., Smiatek, G., Strasser, U., and Kunstmann, H.: A 5 km Resolution Regional Climate Simulation for Central Europe: Performance in High Mountain Areas and Seasonal, Regional and ElevationDependent Variations, 10, 682, https://doi.org/10.3390/atmos10110682, 2019.

685 Warscher, M., Hanzer, F., Becker, C., and Strasser, U.: Monitoring snow processes in the Ötztal Alps (Austria) and development of an open source snow model framework, vEGU21, Copernicus Meetings, https://doi.org/10.5194/egusphereegu21-9101, 2021.

Zanotti, F., Endrizzi, S., Bertoldi, G., and Rigon, R.: The GEOTOP snow module, 18, 3667-3679, https://doi.org/10.1002/hyp.5794, 2004. 